\title{
Water requirement of pomegranate (Punica granatum L.) orchards for season August-March (Mrig bahar)
}

A.D. BHAGAT AND P.G. POPALE

Received : 14.12.2015; Revised : 16.08.2016; Accepted : 03.09.2016

See end of the Paper for authors' affiliation

Correspondence to :

\section{A.D. BHAGAT}

Department of Irrigation and

Drainage Engineering,

Mahatma Phule Krishi

Vidyapeeth, Rahuri, AHMEDNAGAR (M.S.) INDIA

Email : arunbhagat02@

gmail.com
- ABSTRACT : Pomegranate evapotranspiration determined by the effects of various weather conditions were incorporated into reference crop evapotranspiration and crop characteristics into crop co-efficient. The average ETr values over the 31 years were determined by Penman-Monteith method. The probability distributions that were fitted to ETr values are Log normal, Gumbel and Weibull's probability distribution functions. Chi-square test was performed to know the probability distribution of best fit. ETr values at 10 per cent to 90 per cent probability level for PenmanMonteith method using probability distribution of best fit. The values of reference crop evapotranspiration, crop co-efficient, area factor, water requirement and water to be applied would be useful for the irrigation water management of pomegranate. The water was applied through drip system at 90 per cent efficiency to pomegranate plantation spaced at $3 \times 4.5 \mathrm{~m}$. The result reveals, for Mrig bahar the total weekly water to be applied to pomegranate tree at 70 per cent probability level for $1^{\text {st }}$ to $5^{\text {th }}$ year was $112.44,303.08,761.64,1058.5$ and 1327.4 lit/year/tree, respectively.

- KEY WORDS : Reference crop evapotranspiration (ETr), Crop co-efficient (kc), Pomegranate evapotranspiration (ETp), Mrig bahar, Water requirement

— HOW TO CITE THIS PAPER : Bhagat, A.D. and Popale, P.G. (2016). Water requirement of pomegranate (Punica granatum L.) orchards for season August-March (Mrig bahar). Internat. J. Agric. Engg., 9(2) : 130-139, DOI: 10.15740/HAS/IJAE/9.2/130-139. 